\title{
CONSTITUTION OF THE AMERICAN SOCIETY FOR CLINICAL INVESTIGATION (AS AMENDED TO 1959)
}

\section{ARTICLE I. Name}

The name of the Society shall be "The American Society for Clinical Investigation."

\section{ARTICLE II. ОвJECTS}

The objects of the Society shall be the cultivation of clinical research by the methods of the natural sciences; the unification of science and the practice of medicine; the encouragement of scientific investigation by the practitioner, and the diffusion of a scientific spirit among its members.

\section{ARTICLE III. Membership}

Section 1. Eligibility. Any physician residing in the United States or Canada who is less than 45 years old, has accomplished meritorious original investigation in the clinical or allied sciences of medicine and enjoys an unimpeachable moral standing in the medical profession, is eligible to membership.

Section 2. Nomination and Election. Nominations to membership may be made in writing to the Secretary at any time. Such nominations must be signed by two members, active or emeritus, but not by officers of the Society during their tenure of office. Each nomination must be accompanied by (1) a statement from each of the sponsors as to the qualifications of the nominee and (2) a list of the academic degrees, professional positions and publications of the nominee. All names thus placed in nomination prior to January 1 st preceding each annual meeting shall be considered by the Council, which shall pass upon the qualifications of the candidates and report to the Society for election at the annual meeting such names as it shall approve by a two-thirds vote. An affirmative vote of at least three-fourths of the members present shall be necessary for election.

Section 3. The Council shall have authority to recommend each year to the Society the names of properly qualified candidates equal to the number of retiring Active Members, or up to the number of thirty-five, depending on which number is the larger.

The Council shall also report to the Society a list of candidates whose names shall be continued in nomination.

Section 4. Obligations. Members must manifest a continuous interest in the objects of the Society by the following: (1) They must attend at least every other annual meeting. (2) They must be active in the diffusion of the principles of the Society, particularly among their students and professional associates.

Failure to attend two consecutive meetings without an explanation acceptable to the Council carries with it forfeiture of membership.

Members shall be subject to annual dues as set forth in Article IX.

Section 5. Privileges. Members may participate in the business and scientific sessions of the Society and each may submit or sponsor one paper for the scientific program of each annual meeting. Only members are eligible to hold office in the Society.

Section 6. Expulsion. Members may be expelled also for reasons not especially mentioned in the Constitution by a three-fourths vote of the total membership. The vote shall be by secret ballot.

Section 7. Emeritus Members. Members who have reached their forty-fifth birthdays prior to the annual spring meeting of the Society shall automatically become Emeritus Members at the end of that meeting. Members whose membership has extended throughout five years or more may at their own request be transferred by the Council to Emeritus Membership.

Section 8. Each Emeritus Member shall be entitled to attend all meetings, participate in the business and scientific discussion but may not vote or hold office. With respect to the scientific program, an Emeritus Member may introduce one paper by non-members, but may not appear as 
author or co-author. He may also nominate members. He shall be exempt from dues.

\section{ARTICLE IV. OfFicers}

Officers of the Society shall be a President, Vice-President, and Secretary-Treasurer, all to be elected annually. The Editor-in-Chief of the Journal of Clinical Investigation shall be an exofficio member of the Council of the Society. His maximum tenure of office shall be 5 years, and his successor shall be elected, when possible, one year prior to his retirement. In addition each year a Councillor shall be elected to serve three years. However, at the first meeting three Councillors shall be elected, one of whom shall serve one year, one two years, and one three years. The order of retirement of the first Councillors is to be determined by lot. All officers are ineligible for reelection except the Secretary-Treasurer, who may be re-elected twice, the total period of continuous service not to exceed three years. These officers are to be nominated by a committe of three appointed by the President. The election shall be by secret ballot.

\section{ARTICLE V. DUty OF OfFICERS}

The duties of President, Vice-President, and Secretary-Treasurer shall be those usually assigned to these officers. The Secretary-Treasurer shall also arrange for the publication of abstracts of papers presented at the meetings of the Society.

\section{ARTICLE VI. Council}

The Council shall consist of the President, VicePresident, Secretary-Treasurer, Editor of the Journal of Clinical Investigation and the three Councillors. Four members shall constitute a quorum.

It shall be the duty of the Council to supervise the affairs of the Society, to make all the arrangements for the annual meeting, to report on the work of the members, to consider all nominations for membership and to report on them at the meeting at which they shall be balloted on.

There shall be an Editorial Committee of the Society consisting of 15 members not more than one-third of whom shall be emeritus when appointed; these members shall be elected by the
Society upon recommendation of the Editor-inChief in collaboration with the Editorial Committee and with the approval of the Council. The members shall be elected for 5 years with three such appointments being made annually. Initially, the appointments will necessarily require the proper staggering.

A chairman of this Editorial Committee shall be elected annually from among its members, and by its members.

The Editorial Committee shall be responsible for the editorial policies of the Journal and the nomination of the Editor-in-Chief. They shall individually and collectively be available to assist the Editor-in-Chief at his request, in any matters.

In addition, Associate Editors shall be appointed by the Editor-in-Chief and these Associate Editors shall sit with the Editorial Committee at all regular meetings.

\section{ARTICLE VII. Meetings}

The Society shall hold one general meeting annually.

\section{ARTICLE VIII. QUORUM}

Any number of members at the appointed time of the annual meeting shall constitute a quorum for the transaction of ordinary business. For the election of members fifteen shall be necessary for a quorum, and for altering the Constitution forty per cent of the membership shall be necessary.

\section{ARTIClE IX. Annual Dues}

The annual dues of the Society shall be such sum as the Council from time to time may fix. The non-payment of dues for two consecutive years carries with it the forfeiture of membership.

\section{ARTiClE X. Amendments to the Constitution}

Amendments to the Constitution must be proposed in writing by five members at an annual meeting, and must be acted upon at the succeeding annual meeting, notices of which shall contain an announcement of the proposed amendment, and such amendments shall require for their adoption an affirmative vote of three-fourths of those present. 